\title{
Investigation on Antimicrobial Activity of Nickel(II) and Zinc(II) Complexes with Schiff Base Derived from Aminoacid Valine With Citral: Synthesis, Spectroscopic Analysis
}

\author{
M. Bencela ${ }^{1 *}$, S. Sudha Kumari ${ }^{2}$, T.S. Parmila ${ }^{3}$ \\ ${ }^{1,2,3}$ Dept. of Chemistry \& Research center, South Travancore Hindu College, Nagercoil-629 002, Manonmaniam Sundaranar \\ University, Tirunelveli, Tamilnadu, India. \\ *Corresponding Author: bencela88@gmail.com, Tel.: 919585651589
}

Available online at: www.isroset.org

Received: 17/Jul/2019, Accepted: 04/Aug/2019, Online: 31/Aug/2019

\begin{abstract}
Ni}$ (II) and $\mathrm{Zn}(\mathrm{II})$ metal complexes with Schiff base derived from Citral and Valine are synthesised and characterized on the basis of spectroscopic techniques (FT-IR, and UV-Visible) and magnetic susceptibility studies The IR spectral data indicated that the Schiff base coordinated to central $\mathrm{Ni}(\mathrm{II})$ and $\mathrm{Zn}$ (II) ions in a bridged-tridentate and bidentate fashion respectively. Magnetic moment and spectral studies suggest distorted octahedral around the $\mathrm{Ni}(\mathrm{II})$ ion and tetrahedral geomtry around $\mathrm{Zn}$ (II) ion. The preliminary antimicrobial activity has been evaluated against two Gram-negative bacteria; namely, Pseudomonas aeroginosa and Escherichia coli, one gram-positive bacteria Staphylococcus aureus, and antifungal activity are tested against Aspergillus sps and Candida albicans using disc diffusion method. The result revealed that $\mathrm{Ni}$ (II) complex exhibited potent activity when compared to Zn(II) complex and Schiff base.
\end{abstract}

Keywords-Schiff base, Citral, valine, metal complexes, antimicrobial activity.

\section{INTRODUCTION}

Development of novel pharmacologically active Schiff bases and their metal complexes attract the attention of medicinal chemist nowadays. Schiff base and its metal complexes are multifaceted compounds, exhibit a broad range of biological activities, for instance, antibacterial, antifungal, antimalarial, anti-inflammatory, antiviral, etc. [1],[2],[3]. Deep-rooted of transition metal ions to active biological Schiff bases afford new compounds which exhibit a considerable change in intrinsic chemical structure and biological activities, promoted a noteworthy interest in the study of their coordination behaviour [4]. The growing of the area of bioinorganic chemistry has been becoming greater interest in Schiff base transition metal complexes derived from aminoacids since a lot of these complexes exhibit substantial antimicrobial activity [5].

Keeping in view of biological properties of Schiff base transition metal complexes and almost negligible amount of work reported on Schiff base complexes of metals with citral and valine moieties, the present paper aims to synthesize $\mathrm{Ni}(\mathrm{II})$ complex (1a) and Zn(II) complex(1b) with Schiff base obtained from condensation of citral with valine. The synthesised Schiff base M(II) complexes are characterized using FT-IR, UV-Vis, and magnetic susceptibility studies.
The newly synthesized compounds are screened for their antimicrobial activity.

\section{MATERIALS AND METHODOLOGY}

\section{Materials}

All the chemicals used in the preparation of Schiff base and their M(II) complexes were of analytical grade. Citral and Valine were purchased from Spectrochem, and M(II) nitrates were purchased from Merck, used as received without further purification. Ethanol, DMSO, Diethyl ether were used solvents, was of reagent grade.

\section{Physical Measurements}

Fourier transform infrared (FTIR) spectra of the new compounds were recorded in the spectral range 4000-500 $\mathrm{cm}^{1}$ on Perkin Elmer-spectrum one FT-IR Spectrometer. Electronic spectra were recorded using a Perkin Elmer Lambda-950 UV-VIS spectrometer using DMSO as a solvent in the range of 200-800 $\mathrm{nm}$. Magnetic susceptibility measurements of complexes were carried out using Gouy balance at room temperature using $\mathrm{Hg}[\mathrm{Co}(\mathrm{NCS})]$ as an internal reference. 


\section{Synthesis of Schiff base ligand}

The ligand was synthesized by adding hot ethanolic solution of citral $(10 \mathrm{ml}, 0.5 \mathrm{mmol})$ to aqueous solution of valine $(10 \mathrm{ml}, 0.5 \mathrm{mmol})$ and refluxed for 2 hours at $60^{\circ} \mathrm{C}$ during which the color of the mixture turned to yellow-orange. The reaction mixture was further refluxed for 2 hours. The mixture was kept aside without shaking for overnight to afford the brownish red precipitate. The product obtained was repeatedly washed well with hot water and diethyl ether and dried in air.

\section{Preparation of Metal(II) complexes}

The M(II) complexes with above synthesized Schiff base ligand were prepared using an in-situ method by adding an aqueous of metal(II) nitrate $\left(\mathrm{Ni}^{2+}\right.$ and $\left.\mathrm{Zn}^{2+} 0.5 \mathrm{mmol}, 10 \mathrm{ml}\right)$ to the hot ethanolic solution of Schiff base and obtained mixture was continuously refluxed for 3 hours. On cooling the light green $\mathrm{Ni}(\mathrm{II})$ complex (1a) and dirty white $\mathrm{Zn}$ (II) complex (1b) was obtained, which was filtered off and washed well with ethanol, diethyl ether and dried in air.

\section{Antimicrobial activity}

The synthesized Schiff base ligand and its $\mathbf{1 a}$ and $\mathbf{1 b}$ complexes were screened for their antibacterial activity against Staphylococcus aureus (gram positive), Escherichia coli and Pseudomonas aeroginosa (gram negative) using streptomycin as standard drug and antifungal activity against Aspergillus sps and Candida albicans using fluconazole as standard drug using the agar diffusion method. The solvent DMSO is used for dissolving the synthesized compounds. The bacterial strains were cultured in Mueller Hinton agar medium and made to spread over the sterilized Petri dish using a cotton swab. Further, the medium was allowed for solidification. The paper discs which impregnated with standard antibiotics and compounds to be tested were prepared and placed over the surface of the respective medium. The standard antibiotic-impregnated disc was used as positive control, and DMSO impregnated disc was used as negative control. Then the prepared plates were incubated at $37^{0} \mathrm{C}$ for 24 hours under aseptic conditions. Anti-fungal activity was investigated using a modified Kirby Bauer disc diffusion method. The fungal species are spread on to the potato-dextrose agar plate. Precise discs of $6 \mathrm{~mm}$ were developed in medium, well sterilized and then impregnated the discs with the samples to be tested. Standard antibiotic and DMSO were acted as positive and negative control respectively. Plates were incubated at $37^{\circ} \mathrm{C}$ at room temperature for 3-4 days. Zones of inhibition $(\mathrm{mm})$ formed by the synthesized compounds were measured at the end of the incubation period.

\section{RESULTS AND DISCUSSION}

\section{INFRARED SPECTRAL STUDIES}

The comparison of the IR spectra of Schiff base ligand and the complexes can render structural evidence for the mode of coordination of the ligand to the metal center, and their assignments are tabulated in Table1. The IR spectra of Schiff base ligand and its M(II) complexes are shown in Figure 1. In the FT-IR spectrum of Schiff base, the characteristic stretching frequency of the azomethine group, $v(-\mathrm{C}=\mathrm{N}-)$ has occurred at $1608 \mathrm{~cm}^{-1}$, and the $v_{\text {asy }}\left(\mathrm{COO}^{-}\right)$and $v_{\text {sym }}\left(\mathrm{COO}^{-}\right)$ have appeared, respectively at 1587 and $1384 \mathrm{~cm}^{-1}$ [6]. The azomethine band $v(-\mathrm{C}=\mathrm{N}-)$ in Schiff base ligand on complexation, undergoes a considerable shift to higher frequencies values in 1a and 1b complexes (1628 and 1632 $\mathrm{cm}^{-1}$ ) which indicates that the azomethine nitrogen is coordinated to the metal centers. The asymmetric carboxylate $v_{\text {asy }}\left(\mathrm{COO}^{-}\right)$is shifted to lower frequency region $1565 \mathrm{~cm}^{-1}$, and the symmetric carboxylate $\mathrm{v}_{\mathrm{sym}}\left(\mathrm{COO}^{-}\right)$is shifted to higher frequency region $1423 \mathrm{~cm}^{-1}\left[\Delta \mathrm{v}=142 \mathrm{~cm}^{-1}\right]$ in 1a, whereas $1 \mathbf{b} v_{\text {asy }}\left(\mathrm{COO}^{-}\right)$shifted to higher $1581 \mathrm{~cm}^{-1}$, and $v_{\text {sym }}\left(\mathrm{COO}^{-}\right)$shifted to lower $1364 \mathrm{~cm}^{-1}\left[\Delta v=217 \mathrm{~cm}^{-1}\right]$, indicating the linkage between the metal centers and carboxylato oxygen atom. The asymmetric $v_{\text {asy }}\left(\mathrm{COO}^{-}\right)$and symmetric $v_{\text {sym }}\left(\mathrm{COO}^{-}\right)$stretching frequencies of the carboxylate group in the 1a complex shows the separation value $\left(\Delta v=142 \mathrm{~cm}^{-1}\right)$ less than $200 \mathrm{~cm}^{-1}$, indicates the bridging coordination (Ni-O-C-O-Ni) between adjacent $\mathrm{Ni}$ (II) center and the other one shows greater than $200 \mathrm{~cm}^{1}$ $\Delta v$ value, indicates monodentate binding in $\mathbf{1 b}$ complex [7]. Furthermore, the presence of coordinated water molecules as evidenced by the broad band's appeared at $3389-3415 \mathrm{~cm}^{-1}$ in complexes may be attributed to $\mathrm{O}-\mathrm{H}$ stretching vibration. The IR spectra of the complexes show the bands appeared at $1456-1448 \mathrm{~cm}^{-1}, 1322-1318 \mathrm{~cm}^{-1}$ and $960-957 \mathrm{~cm}^{-1}$, which can be ascribed to monodentate coordination of $\mathrm{NO}_{3}$ group The appearance of new non-ligand bands at region 543-516 $\mathrm{cm}^{-1}$ and $449-417 \mathrm{~cm}^{1}$ correspond to $v(\mathrm{M}-\mathrm{O})$ and $v(\mathrm{M}-\mathrm{N})$ vibrations, respectively [8]. The IR spectra confirm that the Schiff base ligand is acting as bridging ligand via carboxlyate moiety thus indicates that $\mathrm{Ni}(\mathrm{II})$ complex is in dimeric/polymeric form. In $\mathbf{1 b}$ complex carboxylate moiety is acting as monodentate nature hence the complex is assigned to monomeric form. Furthermore, suggested that $\mathrm{Ni}(\mathrm{II})$ centers incorporated to Schiff base ligand through azomethine nitrogen, $\mu^{2}$ carboxylato oxygen atoms whereas in $\mathrm{Zn}(\mathrm{II})$ complex ligand coordinated to central metal ion via azomethine nitrogen and carboxylato oxygen atom [9]. Water molecules would complete the other positions in the coordination sphere.

Table 1: IR spectral assignments $\left(\mathrm{cm}^{-1}\right)$ of $\mathrm{Ni}(\mathrm{II})$ and $\mathrm{Zn}(\mathrm{II})$ complexes with $\mathrm{SB}$

\begin{tabular}{|l|c|c|c|c|c|c|c|c|c|}
\hline Compounds & \multirow{2}{*}{$v(\mathrm{C}=\mathrm{N})$} & \multicolumn{3}{|c|}{$\mathrm{COO}-$} & \multicolumn{2}{|c|}{$\mathrm{O}^{-\mathrm{NO}_{2}}$} & \multirow{2}{*}{$\mathrm{N}\left(\mathrm{H}_{2} \mathrm{O}\right)$} & $\mathrm{N} \rightarrow \mathrm{M}$ & $\mathrm{O} \rightarrow \mathrm{M}$ \\
\cline { 3 - 8 } & & $v_{a s y}$ & $v_{s}$ & $v(\Delta)$ & $v_{a s y}$ & $v_{s}$ & & & \\
\hline
\end{tabular}




\begin{tabular}{|c|c|c|c|c|c|c|c|c|c|c|}
\hline SB & 1608 & 1587 & 1384 & 203 & - & - & - & - & - & - \\
\hline (1a) & 1628 & 1565 & 1423 & 142 & 1456 & 1318 & 959 & 3389 & 543 & 449 \\
\hline (1b) & 1632 & 1581 & 1364 & 217 & 1448 & 1322 & 957 & 3415 & 516 & 417 \\
\hline
\end{tabular}

- $\mathrm{SB}=$ schiff base ligand, $1 \mathrm{a}=\mathrm{Ni}$ (II) complex, $1 \mathrm{~b}=\mathrm{Zn}$ (II) complex

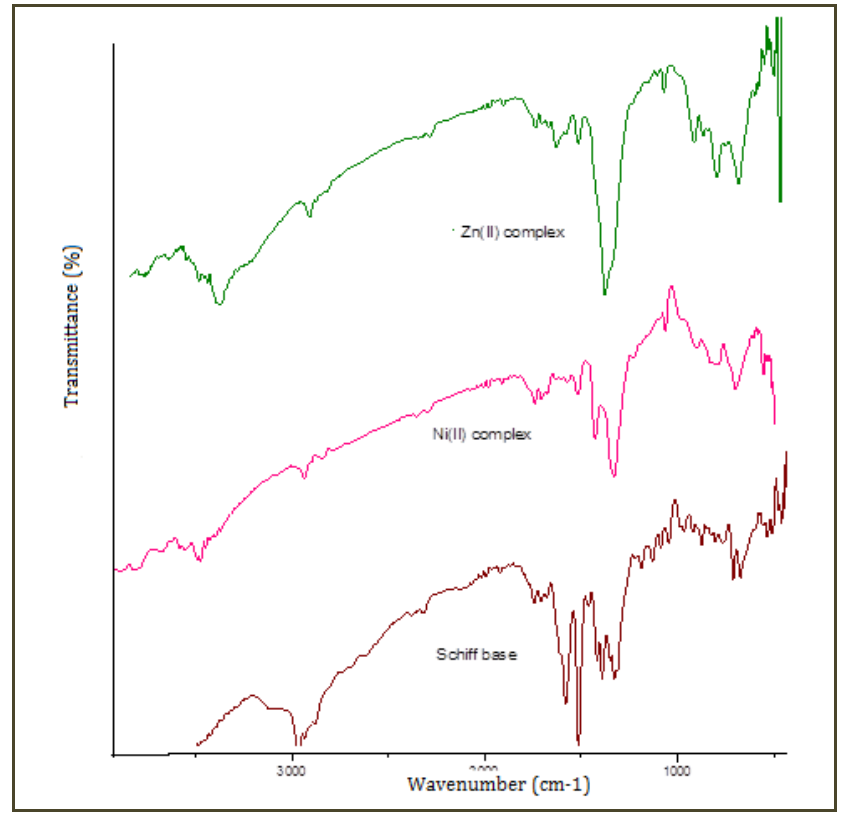

Figure 1. The FT-IR spectra of Schiff base ligand and its $\mathrm{Ni}(I I)$ and $\mathrm{Zn}(\mathrm{II})$ complexes

\section{Magnetic moment and electronic spectral studies}

The information regarding the geometry of the complexes is obtained from their electronic spectral data and magnetic moments. The electronic absorption regions, assignments, and magnetic moment data are given in Table 2. The electronic spectra of Schiff base ligand and its M(II) complexes are shown in Figure 2 and 3.

The observed magnetic moment value of the 1a complex at $300 \mathrm{~K}$ is $1.7 \mathrm{~B} . \mathrm{M}$, which is lower than the expected spin-only value of 2.8 B.M for the octahedral Ni(II) complexes. The very low magnetic moment value indicates the strong antiferromagnetic interaction between two Ni ions. Further, the presence of $\mathrm{Ni}-\mathrm{O}-\mathrm{C}-\mathrm{O}-\mathrm{Ni}$ fragment in the complex is supported by IR spectra. The electronic spectrum of 1a displays the band at $301 \mathrm{~nm}$ is assignable to $\mathrm{n}-\pi^{*}$ transition associated with azomethine coordination to the central metal ion. The band at $659 \mathrm{~nm}$ may be assignable to ${ }^{3} \mathrm{~A}_{2 \mathrm{~g}(\mathrm{~F})} \rightarrow{ }^{3} \mathrm{~T}_{1 \mathrm{~g}}$ (F) $\mathrm{d}$-d transition. The bands displayed at 733 and $751 \mathrm{~nm}$ assignable to ${ }^{3} \mathrm{~A}_{2 \mathrm{~g}} \rightarrow{ }^{1} \mathrm{E}_{\mathrm{g}}$ spin-forbidden transitions. Based on the above observations, distorted octahedral geometry has been predicted for the complex [10].

The electronic spectra of $\mathbf{1 b}$ complex showed two bands around 294, and $449 \mathrm{~nm}$ is attributed to the $n-\pi^{*}$ and charge transfer transitions respectively. Generally, $\mathrm{Zn}(\mathrm{II})$ complexes are in $\mathrm{d}^{10}$ configuration, diamagnetic and do not show any $\mathrm{d}$ $\mathrm{d}$ transitions. Taking into account of the appearance of charge transfer transition around $449 \mathrm{~nm}$ in the electronic spectrum of $\mathbf{1 b}$, and based on the configuration of the $\mathrm{Zn}$ (II) center, a tetrahedral geometry has been proposed for the complex. [11].

Table 2 Electronic spectral (nm) and magnetic moment (B.M) assignments of $\mathrm{Ni}(\mathrm{II})$ and $\mathrm{Zn}$ (II) complexes with $\mathrm{SB}$

\begin{tabular}{|c|c|c|c|c|c|}
\hline \multirow[t]{2}{*}{ Compounds } & \multirow[t]{2}{*}{ Colour } & \multicolumn{3}{|c|}{$\begin{array}{c}\text { Electronic } \\
\text { absorption bands } \\
\text { and their } \\
\text { assignments }(\mathrm{nm})\end{array}$} & \multirow{2}{*}{$\begin{array}{c}\text { Magnetic } \\
\text { moment } \\
\text { B.M } \\
\text { at room } \\
\text { temp }\end{array}$} \\
\hline & & $\begin{array}{l}\mathrm{n}- \\
\pi^{*}\end{array}$ & LMCT & $d-d$ & \\
\hline SB & $\begin{array}{c}\text { Brownish } \\
\text { red }\end{array}$ & 313 & - & - & - \\
\hline $1 \mathrm{a}$ & $\begin{array}{l}\text { Light } \\
\text { green }\end{array}$ & 301 & - & $\begin{array}{l}659, \\
733 \\
\text { and } \\
751\end{array}$ & 1.7 \\
\hline $1 b$ & $\begin{array}{l}\text { Dirty } \\
\text { white }\end{array}$ & 294 & 449 & - & diamagnetic \\
\hline
\end{tabular}

- $\mathrm{SB}=$ schiff base ligand, $1 \mathrm{a}=\mathrm{Ni}(\mathrm{II})$ complex, $1 \mathrm{~b}$ $=\mathrm{Zn}(\mathrm{II})$ complex

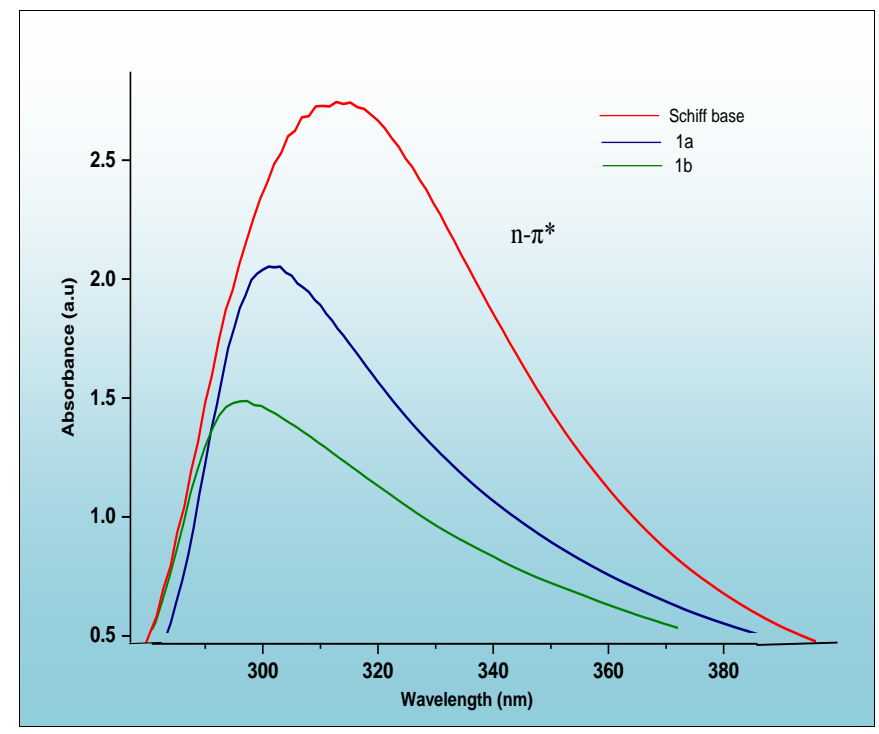

Figure 2. Electronic spectra of $\mathrm{Ni}(\mathrm{II})$ and $\mathrm{Zn}(\mathrm{II})$ with Schiff base ligand ( $n-\pi$ bands) 


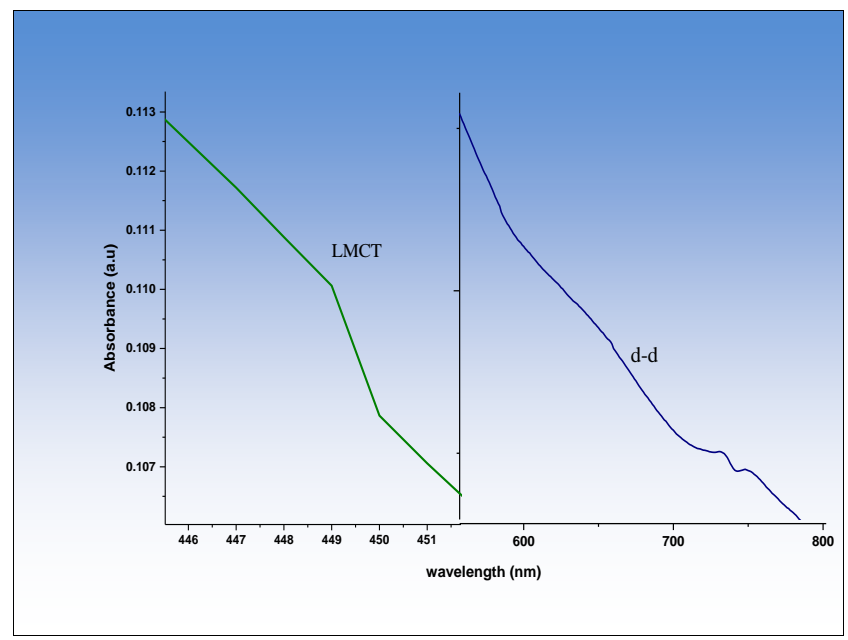

Figure 3. Electronic spectra of $\mathrm{Zn}(\mathrm{II})$ and $\mathrm{Ni}(\mathrm{II})$ complexes with Schiff base ligand (LMCT and d-d transitions)

\section{Antimicrobial Activity}

The antibacterial screening of the Schiff base and its complexes $(10 \mathrm{mg} / \mathrm{ml})$ are carried out against two Gramnegative bacteria, namely, Pseudomonas aeroginosa and Escherichia coli, one gram-positive bacteria Staphylococcus aureus, and antifungal activity is tested against Aspergillus sps and Candida albicans using disc diffusion method using Streptomycin (standard for bacterial strains) and fluconazole (standard for fungal strains) as positive control. The noteworthy $\mathbf{1 b}$ complex is not screened for Pseudomonas aeroginosa (gram-negative), and the growth inhibitory action of ligand and its metal complexes are reported in Table 3. Zone of inhibition recorded by the Schiff base and its metal complexes are shown in Figure 4 and represented as graph in Figure 5. The metal complexes are found to be manifest more activity than the free ligand. The 1a complex displays good inhibition activity against Staphylococcus aureus and Candida albicans, moderate activity against Escherichia coli and Pseudomonas aeroginosa. But $\mathbf{1 b}$ complex revealed only moderate activity against Escherichia coli and Aspergillus sps. The bioactivity of the ligand and its complexes are found to be in the following order: $\mathrm{Ni}$ (II) $>\mathrm{Zn}$ (II) $>\mathrm{SB}$. Generally, the biological activity of $\mathrm{M}$ (II) complexes is influenced by many factors, especially the geometric structure of the complexes. Based on spectral assignments, the structures of the complexes are proposed as bridged geometrical arrangement (1a) and monomeric geometrical arrangement (1b). Hence bridged geometric structure arrangement of 1a complex might be the reason for the enhanced antimicrobial activity, and the low activity of $\mathbf{1 b}$ complex might be owing to low lipophilicity behavior i.e., the $\mathbf{1 b}$ complex is not well enough to penetrate through the outer membrane layer over the cells of the screened microorganisms [12],[13],[14],[15] [16].

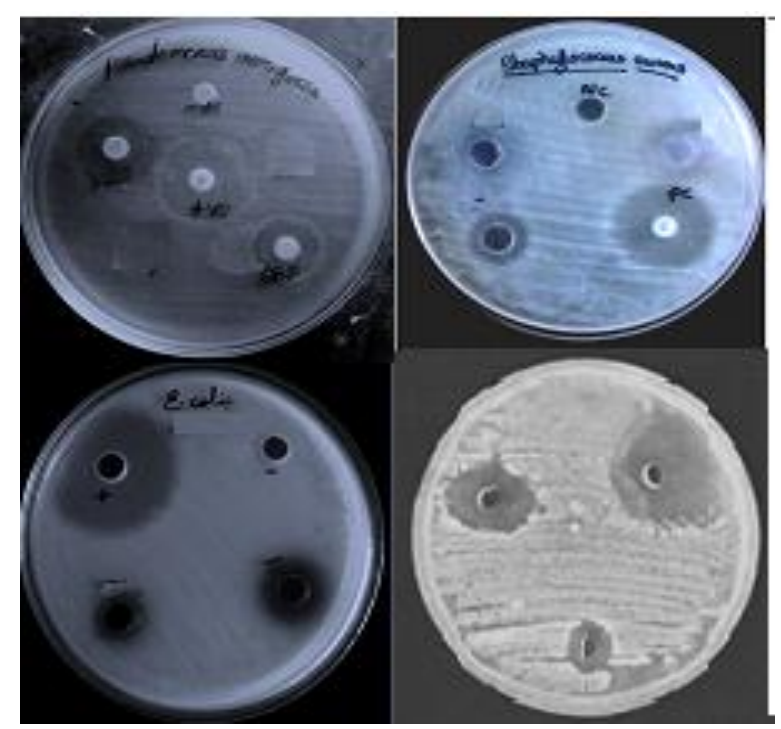

Figure 4. Inhibition zone exposed by Schiff base and its M(II) complexes

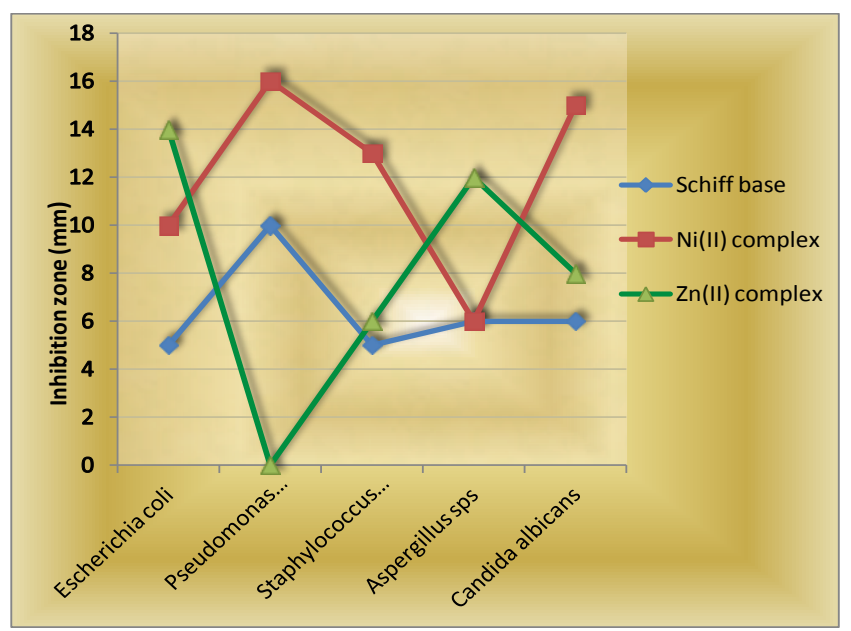

Figure 5. Antimicrobial activities of Schiff base ligand and its M(II) complexes

Table 3: Effect of Schiff base and its Metal(II) complexes on the growth of pathogens $(\mathrm{mm})$

\begin{tabular}{|l|c|c|c|}
\hline \multicolumn{1}{|c|}{ Culture } & SB & $1 \mathrm{a}$ & $1 \mathrm{~b}$ \\
\hline Escherichia coli $(G-)$ & + & ++ & ++ \\
\hline Staphylococcus aureus $(G-)$ & + & ++ & + \\
\hline Pseudomonas aeroginosa $(G+)$ & + & +++ & $\mathrm{x}$ \\
\hline Candida albicans & + & +++ & + \\
\hline Aspergillus sps & + & + & ++ \\
\hline
\end{tabular}

- 15 and above $=+++, 14-10=++,>10=+, x=$ not analyised 
- $\mathrm{SB}=$ schiff base ligand, 1a = Ni(II) complex, $1 \mathrm{~b}$ $=\mathrm{Zn}(\mathrm{II})$ complex

\section{CONCLUSION}

$\mathrm{Ni}$ (II) and $\mathrm{Zn}$ (II) complexes of the Shiff base ligand derived from citral and valine were synthesized and chracterized via FT-IR, UV-Vis and magnetic susceptibility studies. The FT IR spectra demonstrate that the Shiff base ligand coordinated in bridged-tridentate (azomethine nitrogen, $\mu^{2}$ carboxylato oxygen atoms) and bidentate (azomethine nitrogen, carboxylato oxy.gen atoms) fashion around $\mathrm{Ni}(\mathrm{II})$ and $\mathrm{Zn}$ (II) centers respectively. The structure has been proposed as distorted octahedral and tetrahedral for $\mathrm{Ni}$ (II) and $\mathrm{Zn}$ (II) complexes based on electronic spectra. Magnetic moment studies disclosed that $\mathrm{Ni}$ (II) complex is bridged between the $\mathrm{Ni}$ (II) center with anti-ferromagnetic interaction and $\mathrm{Zn}$ (II) complex are diamagnetic in nature. The antimicrobial activity of the ligand and its complexes indicates that the $\mathrm{Ni}$ (II) complex possses potent antimicrobial activity than $\mathrm{Zn}$ (II) complex and parent ligand The bridged structural arrangement of $\mathrm{Ni}(\mathrm{II})$ complex has been propossed as the reason for the enhanced antimicrobial activity.

\section{ACKNOWLEDGMENTS}

We the authors express our sincere gratitude to Head of the department Dr.Vidyanathan, South Travancore Hindu College Nagercoil for the laboratories facilities provide to us. Also, we record our deep gratitude to Dr. J.Joseph, Department of chemistry, Noorul Islam Centre for Higher Education (Deemed University).

\section{REFERENCES}

[1] S.Arulmurugan, H.P. Kavitha and B.R. Venkatraman, "Biological Activities of Schiff Base And Its Complexes," Rasayan Journal of Chemistry, Vol.3, pp. 385-410, 2010.

[2] A.M.A-Dief and I.M.A. Mohamed, "A Review on Versatile Applications of Transition Metal Complexes Incorporating Schiff Bases, " Beni-Suef University Journal of Basic and Applied Sciences. Vol. 4, Issue. 2, pp. 119-133, 2015.

[3] C. M. D. Silva, D. L. D. Silva, L. V. Modolo, R. B. Alves, M. A. D. Resende, C.V.B. Martins, And A.D. Fatima, "Schiff Bases: A Short Review of Their Antimicrobial Activities" Journal of Advanced Research, Vol. 2, Issue. 1, pp. 1-8, 2011.

[4] T. Mallikarjun, I.V. Kasiviswanath, V. Krishna and D. Prabhakara Chary, "Synthesis And Spectral Characterization Of Antimicrobial Activity of The Binuclear $\mathrm{Co}(\mathrm{II}), \mathrm{Ni}(\mathrm{II}), \mathrm{Cu}(\mathrm{II})$ And $\mathrm{Zn}(\mathrm{II})$ Complexes of A Novel Macrocyclic Biphenyl Bridged Schiff Base Ligand", Rasayan Journal of Chemistry, Vol. 10 , Issue.3, pp 1015 - $1024,2017$.

[5] G.F. Qi, Z.Y. Yang and B. D. Wang, "Synthesis, Characterization And DNA-Binding Properties Of Zinc(II) And Nickel(II) Schiff Base Complexes," Transition Metal Chemistry, Vol. 32, Issue. 2, pp.233-239, 2007.

[6] J. Vanco, J. Marek, Z. Travnicek, E. Racanska, J.Muselik, O. Svajlenova, "Synthesis, structural characterization, antiradical and antidiabetic activities of copper(II) and zinc(II) Schiff base complexes derived from salicylaldehyde and $\beta$-alanine," Journal of Inorganic Biochemistry, Vol.102, pp .595-605, 2008.

[7] J. Lv, T.Liu, S. Cai, X. Wang, L.Liu, Y. Wang, "Synthesis, Structure And Biological Activity Of Cobalt(II) And Copper(II) Complexes of Valine-Derived Schiff Bases." Journal of Inorganic Biochemistry, Vol.100, Issue.11, pp.1888-1896, 2006.

[8] N.C. Polfer, J. Oomens, D. T. Moore, G. V. Helden, G. Meijer, and R. C. Dunba, "Infrared Spectroscopy of Phenylalanine Ag(I) and Zn(II)Complexes in the Gas Phase," Journal of American Chemical Society, " Vol.128, pp.517-525, 2006.

[9] G.G. Mohamed, M.M. Omar, and A.A. Ibrahim, "Biological Activity Studies on Metal Complexes Of Novel Tridentate Schiff Base Ligand. Spectroscopic And Thermal Characterization", European Journal Of Medicinal Chemistry," Vol.44, Issue.12, pp 4801-4812, 2009.

[10] Z.R.Dai, C-F.Yin, C.Wang, and J-C.Wua, "Zinc bis-Schiff base complexes: Synthesis, structure, and application in ring-opening polymerization of rac-lactide, " Chinese Chemical Letters, Vol.27, pp. 1649-1654, 2016.

[11] M. S.Jana, A. K. Pramanik, and T.K. Mondal, "Octahedral Ni(II) and $\mathrm{Cu}(\mathrm{II})$ complexes with a new hexadentate (NSN)2 donor ligand Synthesis, characterization, X-ray structure, and DFT calculations", Polyhedron, Vol.76, pp 29-35, 2014.

[12] S.A. Khan, S. A.A. Nami, S. A. Bhat, A.Kareem and N. Nishat, "Synthesis, characterization and antimicrobial study of polymeric transition metal complexes of $\mathrm{Mn}(\mathrm{II}), \mathrm{Co}(\mathrm{II}), \mathrm{Ni}(\mathrm{II}), \mathrm{Cu}(\mathrm{II})$ and Zn(II)", Microbial Pathogenesis, Vol.110, pp. 414-425, 2017.

[13] X. Qin, Y. Ji, Y. Gao, L. Yan, S.Ding, Y. Wang, and Z.Liu, Zinc(II) and Nickel(II) Complexes Based on Schiff Base Ligands: Synthesis,Crystal Structure, Luminescent and Magnetic Properties", Journal of Inorganic and General Chemistry Vol 640, Issue2, pp 462-468, 2014.

[14] A. Stasch, Synthesis, Structure, And Reactivity of A Dimeric Zinc(I) CompoundStabilized By A Sterically Demanding Diiminophosphinate Ligand" Chemistry A European Journal, Vol 18, pp 15105-15112, 2012.

[15] B.K.A. Salami, R. A. Gata and K. A.Asker, "Synthesis Spectral, Thermal Stability and Bacterial Activity of Schiff Bases Derived From Selective Amino Acid and Their Complexes" Advances in Applied Science Research, Vol 8, Issue 3, pp:4-12, 2017.

[16] A. Patra , G P. Sahoo , P. Setua , A. Pandey, and S. Maiti, "Synthesis and characterization of Cadmium(II) complex with tetradentate $\mathrm{N}_{2} \mathrm{O}_{2}$ - donor Schiff base and biological activity" International Journal of Scientific Research in Biological Sciences,Vol.6, Issue.1, pp:270-274, 2019. 